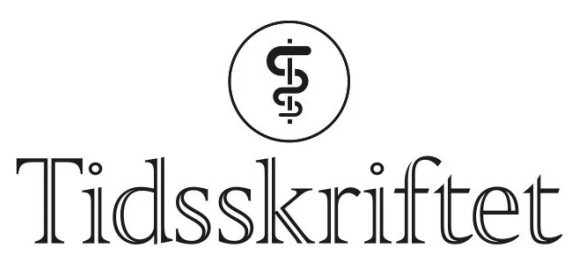

DEN NORSKE LEGEFORENING

\title{
Langvarig syk etter covid-19
}

KRONIKK

ESPEN LINDHOLM

line@ous-hf.no

Espen Lindholm er spesialist i anestesiologi og i indremedisin og er postdoktor ved Avdeling for anestesiologi, Oslo universitetssykehus, Rikshospitalet og forskningsrådgiver ved Kirurgisk klinikk, Sykehuset i Vestfold.

Forfatteren har fylt ut ICMJE-skjemaet og oppgir ingen interessekonflikter.

\section{TOR INGE TØNNESSEN}

Tor Inge Tønnessen er spesialist i anestesiologi og overlege ved Intensivavdelingen, Oslo universitetssykehus, Rikshospitalet og professor ved Institutt for klinisk medisin, Universitetet i Oslo.

Forfatteren har fylt ut ICMJE-skjemaet og oppgir ingen interessekonflikter.

\section{Også pasienter med initialt mildt forløp av covid-19} rapporterer langvarige symptomer i form av blant annet brystsmerter, tungpustethet, hodepine og utmattelse. Mange har nedsatt livskvalitet. Vi har ennå ikke oversikt over langtidsvirkningene av pandemien.

Mer enn 33 millioner mennesker i 235 land har per september 2020 blitt smittet av SARSCoV-2 og har utviklet sykdommen covid-19 (1). Omkring 995 ooo er bekreftet døde (per 28.9.2020), og pandemien og dens konsekvenser $ø$ ker fortsatt. Symptombildet ved covid-19 er svært varierende fra en asymptomatisk tilstand til symptomer som feber, hoste, kortpustethet, smerter i brystet, utmattelse, nevrologiske symptomer som bortfall av smakog luktesans samt magesmerter og andre gastrointestinale symptomer. Alvorlige forløp som krever sykehusinnleggelse og behandling i intensivavdeling er godt beskrevet $\mathrm{i}$ litteraturen $(\underline{\underline{2-10}})$.

Forløpene preges av dysfunksjon i vitale organsystemer, først og fremst lunger (akutt lungesviktsyndrom, ARDS), men alle organsystemer kan bli involvert på grunn av immunog koagulasjonsaktivering. Imidlertid er langvarig sykdomsforløp hos pasienter som gjennomgikk akuttfasen av covid-19 med initialt mild affeksjon av sykdommen, mindre belyst, særlig hos ikke-hospitaliserte individer.

\section{Mange opplever langvarig sykdom}


Det er rapportert at 10-33 \% opplever langvarig sykdom (flere uker og måneder) etter covid19-infeksjon og at dette forekommer dobbelt så hyppig hos kvinner som hos menn (11-13). Det er fremdeles usikkerhet rundt hvor stort omfanget av langvarige symptomer etter akutt fase av covid-19 er. Dette skyldes at sykdommen er ny og at langtidsdata derfor mangler. I tillegg er det store mørketall på hvem som har gjennomgått covid-19. Det er mange pågående oppfølgingsstudier, men de fleste er på hospitaliserte pasienter.

Mange med covid-19 har vært i hjemmeisolasjon basert på et klinisk forløp uten å ha blitt testet, siden det bare er de siste månedene testkapasiteten har vært god nok. Disse pasientene har mindre sannsynlighet for å bli med i oppfølgingsstudier. I en nylig publisert studie fant man at visse symptomkomplekser var assosiert med økt risiko for å få langvarige symptomer. Hvis pasienten i løpet av den første uken med covid-19 hadde en kombinasjon av vedvarende hoste, heshet, hodepine, kortpustethet og betydelig nedsatt appetitt, var sannsynligheten for å få langvarige symptomer i etterkant $\emptyset \mathrm{kt}$ med 2-3 ganger (14).

«Det er rapportert at 10-33 \% opplever langvarig sykdom etter covid-19infeksjon og at dette forekommer dobbelt så hyppig hos kvinner som hos menn»

Det er kjent at andre virusinfeksjoner kan gi langvarige følgetilstander (postvirale syndromer). Langvarige virkninger av covid-19 er imidlertid foreløpig lite kjent og undersøkt, og det er usikkert i hvilken grad man kan ekstrapolere andre postvirale syndromer til covid-19-affiserte pasienter (15). Det kommer et økende antall rapporter om langvarige forløp av covid-19. Noen av disse bekrivelsene stammer fra leger som selv har gjennomgått sykdommen og som i etterkant av det akutte forløpet angir langvarige symptomer (16-18). Andre gjengir større populasjoner (1ㅡ), (19-20).

I en spørreundersøkelse blant både hospitaliserte og ikke-hospitaliserte covid-19-pasienter med verifisert SARS-CoV-2, ble respondentene kontaktet 14-21 dager etter testing. Omtrent en tredjedel $(36 \%)$ av de ikke-hospitaliserte pasientene angav at de ikke var tilbake til sin habituelle tilstand. De vanligste symptomene var pleurittisk smerte $(74 \%)$, utmattelse (70 \%), hodepine ( $62 \%)$, hoste (62\%), kroppssmerter (58\%), feber (55\%), frysninger (52\%) og manglende smaks- og luktesans (52\%) (1ㅡ). I en annen nylig publisert artikkel fra Italia beskriver forskerne vedvarende symptomer i en populasjon på 143 pasienter som ble fulgt opp i gjennomsnittlig 6o dager etter sykehusinnleggelse for covid-19 (19).). Kun 18 (12,6\%) av disse pasientene hadde blitt behandlet på intensivavdelingen, så de fleste hadde et ikkealvorlig akutt forløp. 21 pasienter (15\%) fikk ikke-invasiv ventilasjon og 7 pasienter (5\%) fikk invasiv ventilasjon. Av de 143 pasientene var bare 18 (12,6\%) helt fri for noen covid-19relaterte symptomer. En betydelig andel rapporterte fortsatt utmattelse (53\%), tungpustethet (43\%), leddsmerter, (27\%) og brystsmerter (22\%). I tillegg ble redusert livskvalitet beskrevet hos $44 \%$ av pasientene.

\section{Affeksjon av hjertet}

Puntmann og medarbeidere utførte hjerteundersøkelser hos en kohort på 1oo pasienter

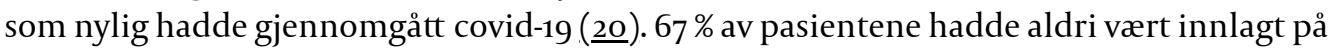
sykehus i forbindelse med den akutte fasen av sykdommen. Median tidsintervall mellom påvist covid-19- sykdom og undersøkelsen var 71 (64-92) dager. Pasientene fikk utført en MR-undersøkelse av hjertet, der man påviste affeksjon av myokard i form av redusert ejeksjonsfraksjon, høyere venstre ventrikkel-volum, økt høyre og venstre ventrikkelmasse, samt forhøyede T1- og T2-verdier hos 78 pasienter (78\%). 6o pasienter (6o \%) hadde en pågående inflammasjonstilstand i myokard. I tillegg fant man forhøyet troponin T hos 71 (71\%) pasienter. Hos dem med betydelig affeksjon ble det i tillegg gjort en endomyokardial 
biopsi, som påviste aktiv lymfocytisk inflammasjonstilstand. Disse funnene var uavhengige av covid-19-sykdommens initiale alvorlighet og tiden fra diagnosetidspunkt til utført billeddiagnostikk. Det må understrekes at det i denne studien ikke var noen kontrollgruppe, men kun en observasjon av en pasientgruppe som hadde gjennomgått covid-19.

\author{
«Langvarig sykdom etter covid-19 rammer også mennesker som har \\ opplevd en mild akutt infeksjon, og forekommer også i relativt unge \\ aldersgrupper»
}

Det kan virke som om disse langvarige sykdomsforløpene har et syklisk forløp, der symptomene kan avta i styrke for så å øke igjen (13,21). Det er uklart om disse symptomene

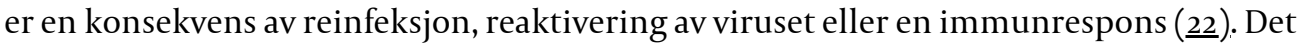
blir stadig tydeligere at covid-19 hos visse individer gir opphav til en langvarig sykdom. Langvarig sykdom etter covid-19 rammer også mennesker som har opplevd en mild akutt infeksjon, og forekommer også i relativt unge aldersgrupper (11), (19-20), (23). Dette kan få implikasjoner for arbeidslivet med langvarig sykefravær. Disse langtidssymptomene har stor effekt på livskvaliteten, vil kreve en mangefasettert oppfølging og kan få betydelige samfunnsøkonomiske konsekvenser. Det vil kreve tverrfaglige innsats med rehabilitering og en gradvis individuelt tilpasset tilbakevending til arbeid etter sykefraværet.

Fagrådet for rehabilitering i Helse Sør- $\emptyset$ st har utarbeidet et pasientforløp for rehabilitering av pasienter innlagt med covid-19-sykdom i spesialisthelsetjenestene (24.). Både Sunnaas sykehus og Sykehuset i Vestfold er i gang med å rehabilitere covid-19-pasienter. Imidlertid er tilbudet foreløpig rettet inn mot tidligere hospitaliserte covid-19-pasienter. De ikkehospitaliserte med langvarige symptomer samt tilsvarende individer med gjennomgått akuttfase av sykdommen, men som aldri fikk anledning til å teste seg, kan risikere å havne mellom to stoler. En annen mulig fallgruve er at man hittil har svært lite sikker kunnskap om langtidssykdom ved covid-19. Noen leger kan derfor ha en viss avvisende holdning overfor disse pasientene, som må møtes med et helhetlig og pragmatisk syn fokusert på symptomhåndtering og forsøk på å unngå overdiagnostikk (1ㅡ,23).

\title{
Mange ubesvarte spørsmål
}

Det er fortsatt mange ubesvarte spørsmål: Hvorfor er noen individer asymptomatiske, mens andre utvikler dødelig sykdom? Hvorfor går noen mennesker fra et mildt forløp til langvarig sykdom, mens andre pasienter med alvorlig infeksjon ser ut til å unngå langtidseffekter? Oppfølgingsstudier er presserende og må omfatte et bredt spekter av tilnærminger, inkludert grundig kartlegging av fysisk status, organfunksjon, kognitiv og emosjonell dysfunksjon, immunologisk respons både med tanke på det medfødte og det ervervede immunsystemet, i tillegg til genetiske studier for å identifisere mulige mønstre som gir mer kunnskap om de mer kompliserte sykdomsforløpene.

\section{"Disse langtidssymptomene har stor effekt på livskvaliteten, vil kreve en mangefasettert oppfølging og kan få betydelige samfunnsøkonomiske konsekvenser»}

Det er fortsatt uavklart hvorvidt alle individer med langvarige symptomer vil bli 10o \% friske igjen eller om en viss andel vil ha vedvarende restsymptomer (프). Vi kan håpe at disse pasientene etter hvert tilfriskner spontant ved helhetlig støtte, hvile, symptomatisk behandling og gradvis økning i aktivitet. 
På det nåværende tidspunktet har vi ikke systematisk kunnskap om langtidsvirkninger av covid-19. De rapportene vi har om de ulike manifestasjonene, bør forstås som en indikasjon på at enkeltindivider kan oppleve ulike følgetilstander, men at sammenhengen mellom disse og gjennomgått covid-19-sykdom fortsatt er usikker. Det er avgjørende at vår kunnskap om langtidseffekter er forskningsbaserte for å unngå unødvendige diskusjoner basert på manglende kunnskap. De fleste pasientene som gjennomgår covid-19 har korte forløp og meget god prognose, mens en mindre del bærer den store byrden med langtidseffekter. Det er denne gruppen som trenger $\varnothing \mathrm{kt}$ fokus. Det siste kapittelet i læreboka om covid-19 er ennå ikke skrevet.

\section{LITTERATUR}

1. WHO. Coronavirus disease (COVID-19) dashboard. https://covid19.who.int/ Lest 20.9.2020.

2. Wiersinga WJ, Rhodes A, Cheng AC et al. Pathophysiology, transmission, diagnosis, and treatment of coronavirus disease 2019 (COVID-19): A review. JAMA 2020; 324: 782-93. [PubMed][CrossRef]

3. Helms J, Kremer S, Merdji H et al. Neurologic features in severe SARS-CoV-2 infection. N Engl J Med 2020;382: 2268-70. [PubMed][CrossRef]

4. Zhao X-Y, Xu XX, Yin H-S et al. Clinical characteristics of patients with 2019 coronavirus disease in a non-Wuhan area of Hubei Province, China: a retrospective study. BMC Infect Dis 2020; 20: 311. [PubMed][CrossRef]

5. Klok FA, Kruip MJHA, van der Meer NJM et al. Incidence of thrombotic complications in critically ill ICU patients with COVID-19. Thromb Res 2020; 191:145-7. [PubMed][CrossRef]

6. Mao R, Qiu Y, He JS et al. Manifestations and prognosis of gastrointestinal and liver involvement in patients with COVID-19: a systematic review and meta-analysis. Lancet Gastroenterol Hepatol 2020; 5: 667-78. [PubMed][CrossRef]

7. Long B, Brady WJ, Koyfman A et al. Cardiovascular complications in COVID-19. Am J Emerg Med 2020;38:1504-7. [PubMed][CrossRef]

8. Chen YT, Shao SC, Hsu CK et al. Incidence of acute kidney injury in COVID-19 infection: a systematic review and meta-analysis. Crit Care 2020; 24:346. [PubMed][CrossRef]

9. Xu Z, Shi L, Wang Y et al. Pathological findings of COVID-19 associated with acute respiratory distress syndrome. Lancet Respir Med 2020; 8: 420-2. [PubMed][CrossRef]

10. Hendren NS, Drazner MH, Bozkurt B et al. Description and proposed management of the acute COVID-19 cardiovascular syndrome. Circulation 2020; 141: 1903-14. [PubMed][CrossRef]

11. Tenforde MW, Billig Rose E, Lindsell CJ et al. Characteristics of adult outpatients and inpatients with COVID-19-11 Academic Medical Centers, United States, March-May 2020. MMWR Morb Mortal Wkly Rep 2020; 69: 841-6. [PubMed][CrossRef]

12. Greenhalgh T, Knight M, A'Court C et al. Management of post-acute covid-19 in primary care. BMJ 2020; 370: m3026. [PubMed][CrossRef]

13. Nabavi N. Long covid: How to define it and how to manage it. BMJ 2020;370: m3489. [PubMed] [CrossRef]

14. Wise J. Covid-19: Study reveals six clusters of symptoms that could be used as a clinical prediction tool. BMJ 2020; 370: m2911. [PubMed][CrossRef]

15. Yelin D, Wirtheim E, Vetter P et al. Long-term consequences of COVID-19: research needs. Lancet Infect Dis 2020; 20: S1473-3099(20)30701-5. [PubMed][CrossRef]

16. Tanner C. The people who can't shake off coronavirus: 'Week nine and I'm exhausted and back to being bed bound'. iNews 21.5.2020. https://inews.co.uk/news/coronavirus-covid-19-symptoms-uklatest-fatigue-breathlessness-long-term-effects-429493 Lest 20.9.2020.

17. Garner P. Paul Garner: For 7 weeks I have been through a roller coaster of ill health, extreme emotions, and utter exhaustion. theBMJopinion 5.5.2020. https://blogs.bmj.com/bmj/2020/05/o5/paulgarner-people-who-have-a-more-protracted-illness-need-help-to-understand-and-cope-with-theconstantly-shifting-bizarre-symptoms/ Lest 20.9.2020.

18. Draulans D. 'Finally, a virus got me.' Scientist who fought Ebola and HIV reflects on facing death from COVID-19. Science 8.5.2020. https://www.sciencemag.org/news/2020/05/finally-virus-got-mescientist-who-fought-ebola-and-hiv-reflects-facing-death-covid-19 Lest 20.9.2020. 
19. Carfi A, Bernabei R, Landi F. Persistent symptoms in patients after acute COVID-19. JAMA 2020;324: 603-5. [PubMed][CrossRef]

20. Puntmann VO, Carerj ML, Wieters I et al. Outcomes of cardiovascular magnetic resonance imaging in patients recently recovered from coronavirus disease 2019 (COVID-19). JAMA Cardiol 2020; 5. doi: 10.1001/jamacardio.2020.3557. [PubMed][CrossRef]

21. Wang X, Xu H, Jiang $\mathrm{H}$ et al. Clinical features and outcomes of discharged coronavirus disease 2019 patients: a prospective cohort study. Q[M 2020;113: 657-65. [PubMed][CrossRef]

22. Batisse D, Benech N, Botelho-Nevers E et al. Clinical recurrences of COVID-19 symptoms after recovery: viral relapse, reinfection or inflammatory rebound? J Infect 2020; 4. doi: 10.1016/j.jinf.2020.06.073. [CrossRef]

23. Godlee F. Living with covid-19. BMJ 2020;370: m3392. [CrossRef]

24. Helse $\emptyset r-\emptyset$ st. Bedre rehabiliteringstilbud til covid-19 pasientene. https://www.helsesorost.no/nyheter/bedre-rehabiliteringstilbud-til-covid-19-pasientene Lest 20.9.2020.

Publisert: 29. september 2020. Tidsskr Nor Legeforen. DOI: 10.4045/tidsskr.20.0753

Mottatt 20.9.2020, godkjent 23.9.2020.

(C) Tidsskrift for Den norske legeforening 2023. Lastet ned fra tidsskriftet.no 26. april 2023. 